\title{
ЕФЕКТИВНІСТЬ ВИКОРИСТАННЯ КОМПРЕСІЙНОГО ОДЯГУ ТА СИЛІКОНОВИХ ПЛАСТИН ДЛЯ ПРОФІЛАКТИКИ ТА ЛІКУВАННЯ ПАТОЛОГІЧНИХ РУБЦІВ ШКІРИ У ПАЦІЄНТІВ ПІСЛЯ ТРАВМ ТА ОПЕРАЦІЙ
}

\section{Тернопільський національний медичний університет імені І. Я. Горбачевського МОз України}

РЕЗЮмЕ. Реабілітація потерпілих з опіками, травмами та після операцій завжди була й залишається актуальною, адже навіть обмежені ураження шкіри, які не становлять проблеми для хірурга в плані їхнього загоєння або оперативного лікування, можуть викликати розвиток рубцевих масивів з деформаціями, контрактурами, алопеціями й трофічними виразками. Незважаючи на те, що існує багато методів профілактики та лікування рубців, їх результативність залишається не завжди задовільною.

Мета - вивчити ефективність профілактики та лікування післяопікових гіпертрофічних та келоїдних рубців на основі вивчення клініко-морфологічних особливостей їх формування при використанні аплікацій силіконових пластин і компресійного одягу.

Матеріал і методи. Проведено порівняння ефективності профілактичних та лікувальних заходів у 65 хворих з післяопіковими рубцями, які виникли після поверхневих та глибоких опіків площею від 5 до 20 \% поверхні тіла. Серед обстежених хворих з опіками було 30 осіб (46,2 \%) чоловічої та 35 (53,8 \%) жіночої статі віком від 9 до 64 років. Пацієнти були поділені на 3 групи. У першу групу ввійшли 30 хворих, в яких через 3-5 днів після повної епітелізації опікових ран використовували силіконові пластини та компресійний одяг на ділянки, в яких розпочалосяутворення рубців; другу-19хворих, яким силіконовіпластинита компресійний одягвикористовували через 20-30 днів після повної епітелізації опікових ран. Третю групу склали 16 пацієнтів із застарілими (1-3 роки після опіків) рубцями, яким була проведена кріодеструкція, ксенопластика, з аплікаціями силіконових пластин після повної епітелізації післяопераційних ран.

Результати. При клінічному обстеженні пацієнтів першої групи, які протягом 4 місяців використовували аплікації силіконових пластин та компресійний одяг, лише в двох пацієнтів (6,6 \%) виявлено гіпертрофічні рубці, які призвели до незначних косметичних дефектів шкірних покривів, у 9 (30 \%) пацієнтів відзначався яскраворожевий колір шкірних покривів протягом перших двох місяців, у інших 19 пацієнтів утворення патологічних рубців не виявлено.

Аналіз результатів лікування пацієнтів другої групи, яким силіконові пластини накладали на гіпертрофічні та келоїдні рубці через 20-30 днів після епітелізації опікових ран протягом 4 місяців, проводився за допомогою універсальної шкали. Загальна сума балів після проведеного лікування зменшилася в 2,6 раза, що свідчить про значну ефективність вказаного методу лікування. Електронно-мікроскопічне дослідження рубців після застосування силіконових пластин показало, що в сполучній тканині помітно знижувався вміст фібробластів, спроможних до інтенсивного колагеноутворення. Застосування силіконових пластин під час загоєння тяжких опікових ран приводилодопокращення епітелізації, зникнення запальногопроцесу, значногозменшенням кількостідерматогенних ускладнень.

Висновки. Клінічно та морфологічно встановлено високу ефективність застосування силіконових пластин та компресійної терапії, а також кріодеструкції з ксенопластикою, для профілактики утворення та лікування патологічних рубців.

КЛючОВІ СлОВА: силіконові пластини; компресійний одяг; келоїдний рубець; гіпертрофічний рубець.

Вступ. Термічні травми є дуже поширеними пошкодженнями, які складають 5,6-12 \% від усіх інших травм $[18,20]$. Завдяки сучасним методам і принципам лікування, впровадженню у практику нових препаратів для парентерального введення, засобів місцевої дії, тимчасових замінників шкіри, досягнуто позитивного впливу на перебіг опікової хвороби та ранового процесу $[1,2]$.

Проте лікування опікових ран завжди поєднане з підвищеним ризиком виникнення патологічних рубців. За даними авторів, рубці спостерігаються у 30-67 \% пацієнтів, які перенесли опікову травму $[9,10,20,21]$. Патологічне рубцювання призводить до розвитку у хворих функціональ- них та косметичних порушень $[24,25]$, викликає тяжкі психологічні наслідки.

Післяопікові рубцеві деформації $€$ пізніми ускладненнями опіків і трапляються досить часто $[14,17]$. При локалізації рубців у ділянці суглобів розвиваються деформації, контрактури й анкілози, що призводять до різних порушень функції кінцівок. Частота утворення келоїдних рубців після опіків складає 12-21\%. Деякі автори спостерігали їх у половини опечених, що лікувалися в стаціонарі [24], інші - тільки в 6-8\% [28].

Приблизно 75 \% реконвалесцентів показане лікування консервативними методами, а $40 \%$ дорослих і близько 35 \% дітей, які перебували на 
Огляди літератури, оригінальні дослідження, погляд на проблему, випадок з практики, короткі повідомлення лікуванні з глибокими опіками, мають потребу у відновному хірургічному лікуванні [14].

Реабілітація потерпілих з опіками завжди була й залишається актуальною у зв'язку з тим, що навіть обмежені ураження шкіри, які не становлять проблеми для хірурга в плані їхнього загоєння або оперативного лікування, можуть викликати розвиток рубцевих масивів з деформаціями, контрактурами, алопеціями й трофічними виразками $[9,20]$. Незважаючи на те, що існують багато методів профілактики та лікування рубців, їх результативність не завжди є задовільною [20].

В останні роки в біомедичній галузі почали успішно використовувати силікон - полімерну сполуку кремнійорганічної природи - як матеріал, що має властивості рідких і фотонних кристалів, діелектриків та хвилеводів [29, 30]. Перший досвід використання силікону в медичній практиці пов'язаний із його пружноеластичними властивостями, що знайшло реалізацію в пластичній і косметичній медицині у вигляді алопластичного матеріалу [31].

Вищенаведене визначає необхідність розробки та впровадження нових методів профілактики та лікування післяопікових келоїдних та гіпертрофічних рубців, зокрема використання силіконових пластин.

Мета - підвищити ефективність профілактики та лікування післяопікових гіпертрофічних та келоїдних рубців на основі вивчення клініко-морфологічних особливостей їх формування при використанні аплікацій силіконових пластин та компресійної терапії.

Матеріал і методи дослідження. В ході клінічних випробувань вивчали ефективність коригування процесу епітелізації ран з метою профілактики утворення рубців. Силіконові пластини виробництва ТОВ «Інститут біомедичних технологій», м. Тернопіль, накладали безпосередньо на епітелізовані післяопікові поверхні ран, фіксували їх на шкірі індивідуально пошитим компресійним одягом. Пластина повністю закривала післяопікову поверхню або площу рубця і заходила за його межі на 0,5-1,0 см 3 усіх сторін. Для кращої «акліматизації» шкіри силіконові пластини розпочинали носити поступово: першого дня протягом 8 годин, а далі збільшували час використання на дві години на день, аж до оптимального 24-годинного використання. Середній термін застосування становив від 2 до 4 місяців.

Всі хворі були поділені на 3 групи:

1. У першу групу ввійшли 30 хворих, в яких через 3-5 днів після повної епітелізації опікових ран використовували пластини на ділянки, в яких розпочалося утворення рубців;

2. У другу групу ввійшли 19 хворих, яким пластини накладали на гіпертрофічні та келоїдні рубці через 20-30 днів після загоєння ран;

3. У третю групу ввійшли 16 пацієнтів із застарілими (1-3 роки після опіків) гіпертрофічними та келоїдними рубцями, яким була проведена кріодеструкція, ксенопластика, з аплікаціями силіконових пластин після повної епітелізації післяопераційних ран (табл. 1).

Таблиця 1. Розподіл хворих залежно від терміну утворення рубця і глибини ураження

\begin{tabular}{|l|c|c|c|}
\hline \multirow{2}{*}{ Серія спостережень (клінічні підгрупи хворих) } & \multicolumn{3}{|c|}{ Кількісний розподіл хворих } \\
\cline { 2 - 4 } & $\begin{array}{c}\text { загальна } \\
\text { кількість }\end{array}$ & $\begin{array}{c}\text { після поверхневих } \\
\text { опіків }\end{array}$ & $\begin{array}{c}\text { після глибоких } \\
\text { опіків }\end{array}$ \\
\hline $\begin{array}{l}\text { Пацієнти із післяопіковими ділянками (3-5 днів після } \\
\text { епітелізації ран) }\end{array}$ & 30 & 18 & 7 \\
\hline Пацієнти з рубцями (20-30 днів після епітелізації ран) & 19 & 12 & 8 \\
\hline $\begin{array}{l}\text { Пацієнти з застарілими рубцями (1-3 роки) після } \\
\text { опіків) }\end{array}$ & 16 & 8 & 27 \\
\hline Разом & 65 & 38 & \\
\hline
\end{tabular}

Огляд пацієнтів починали з загальної оцінки зовнішнього вигляду рубця. Для цього використали «Універсальну шкалу оцінки післяопікових рубців (Фісталь Н. Н.), яка є модифікацією відомої Ванкуверської шкали Vancouver Scar Scale (Baryza М. J., Вагуzа G. А., 1995), до якої включені всі найважливіші симптоми (табл. 2). При первинному огляді визначалася сума балів (максимально - 32), стан рубцевої тканини вводили в протокол і фотографували. Повторні огляди проводили через 2 і 4 місяці після постійного використання силіконових пластин, оцінювали суму балів і порівнювали з попередньою.

Для гістологічного дослідження біопсійний матеріал фіксували в 10 \% нейтральному формаліні, зневоднювали в спиртах зростаючої концентрації і заливали в парафін. Отримані на санному мікротомі зрізи фарбували гематоксиліном та еозином. Гістологічні препарати досліджували і документували за допомогою мікроскопа 
Огляди літератури, оригінальні дослідження, погляд на проблему, випадок з практики, короткі повідомлення Таблиця 2. Універсальна шкала оцінки рубців

\begin{tabular}{|c|c|c|}
\hline Ознака & Методика & Кількість балів \\
\hline Товщина рубця & $\begin{array}{c}\text { Визначення рівня розташування } \\
\text { рубця над поверхнею навколишньої } \\
\text { здорової шкіри }\end{array}$ & $\begin{array}{c}0 \text { - на рівні здорової шкіри; } \\
1 \text { - до } 1 \text { мм над рівнем здорової шкіри; } \\
2 \text { - до } 2 \text { мм над рівнем здорової шкіри; } \\
\text { 3 - від } 2 \text { мм до } 5 \text { мм над рівнем здорової шкіри; } \\
\text { 4-більше } 5 \text { мм над рівнем здорової шкіри }\end{array}$ \\
\hline $\begin{array}{l}\text { Рівномірність } \\
\text { товщини рубця }\end{array}$ & $\begin{array}{c}\text { Визначення рівномірності товщини } \\
\text { рубця на всій його поверхні }\end{array}$ & $\begin{array}{c}\text { 0 - рівномірна товщина; } \\
1 \text { - } 25 \text { \% площі рубця має нерівномірну товщину; } \\
\text { 2-50 \% площі рубця має нерівномірну товщину; } \\
\text { 3-75 \% площі рубця має нерівномірну товщину; } \\
\text { 4- нерівномірна товщина всього рубця }\end{array}$ \\
\hline $\begin{array}{c}\text { Васкуляризація } \\
\text { рубця }\end{array}$ & $\begin{array}{c}\text { Визначення кольору рубця залежно } \\
\text { від ступеня його васкуляризації }\end{array}$ & $\begin{array}{c}0 \text { - колір непошкодженої шкіри; } \\
1 \text { - рожевий колір рубця; } \\
2 \text { - червоний колір рубця; } \\
\text { 3- багряно-ціанотичний колір рубця }\end{array}$ \\
\hline Пігментація рубця & $\begin{array}{c}\text { Визначення наявності пігменту в } \\
\text { рубцевій тканині }\end{array}$ & $\begin{array}{c}0 \text { - нормопігментація рубця; } \\
1 \text { - гіпопігментація рубця; } \\
2 \text { - змішана пігментація рубця; } \\
\text { 3 - гіперпігментація рубця }\end{array}$ \\
\hline Консистенція рубця & $\begin{array}{c}\text { Визначення щільності та рухливості } \\
\text { рубцевої тканини }\end{array}$ & $\begin{array}{c}\text { 0 - береться в складку; } \\
1 \text { - береться в складку із зусиллям; } \\
2 \text { - щільний, малорухомий; } \\
\text { 3- щільний, нерухомий }\end{array}$ \\
\hline Виразкування рубця & $\begin{array}{c}\text { Визначення наявності виразкових } \\
\text { дефектів на поверхні рубця }\end{array}$ & $\begin{array}{c}\text { 0-виразок немає; } \\
1 \text { - виразки в стадії загоєння; } \\
2 \text { - персистуюча виразка; } \\
\text { 3- прогресуюча виразка }\end{array}$ \\
\hline Температура рубця & $\begin{array}{c}\text { Визначення температури рубця } \\
\text { індикаторним термометром } \\
\text { і порівняння з температурою } \\
\text { здорової шкіри }\end{array}$ & $\begin{array}{c}0 \text { - відповідає температурі прилеглої } \\
\text { непошкодженої шкіри; } \\
1 \text { - нижче температури прилеглої непошкодженої } \\
\text { шкіри; } \\
2 \text { - вище на } 0,5^{\circ} \mathrm{C} ; \\
3-\text { вище на } 1^{\circ} \mathrm{C}\end{array}$ \\
\hline $\begin{array}{c}\text { Свербіж, парестезії } \\
\text { рубця }\end{array}$ & $\begin{array}{c}\text { Виявлення зазначених симптомів } \\
\text { у пацієнтів і наявності екскоріацій } \\
\text { рубця }\end{array}$ & $\begin{array}{c}\text { 0-симптоми відсутні; } \\
1 \text {-слабкі, непостійні; } \\
2-\text { постійні; } \\
\text { 3-виражені; }\end{array}$ \\
\hline $\begin{array}{c}\text { Прогресування } \\
\text { рубця }\end{array}$ & $\begin{array}{l}\text { Виявлення прогресування } \\
\text { рубця шляхом опитування і } \\
\text { спостереження }\end{array}$ & $\begin{array}{c}0-\text { не прогресує; } \\
1 \text { - слабке прогресування рубця; } \\
2 \text { - помірне прогресування рубця; } \\
\text { 3- швидке прогресування }\end{array}$ \\
\hline Чутливість & $\begin{array}{c}\text { Порівняння чутливості } \\
\text { (температурної, больової, } \\
\text { тактильної) рубцевої тканини та } \\
\text { прилеглої непошкодженої шкіри }\end{array}$ & $\begin{array}{c}0 \text { - чутливість не відрізняється; } \\
1 \text { - підвищена; } \\
\text { 2-знижена; } \\
\text { 3-відсутня }\end{array}$ \\
\hline
\end{tabular}

лОМО Биолам И та системи візуального аналізу.

Для електронномікроскопічних досліджень маленькі шматочки тканини попередньо фіксували в 2,5 \% розчині глютаральдегіду з активною реакцією середовища $\mathrm{pH} 7,2-7,4$, приготованому на фосфатному буфері Міллоніга. Постфіксацію здійснювали 1 \% розчином чотириокису осмію на буфері Міллоніга протягом 60 хвилин, після чого проводили дегідратацію матеріалу в спиртах і ацетоні та заливали в епоксидні смоли згідно з загальноприйнятою методикою. Ультратонкі зрізи рубцевої тканини, виготовлені на ультрамікротомі УМПТ-7, фарбували 1 \% водним розчином уранілацетату, контрастували цитратом свинцю згідно з методом Рейнольдса та вивчали в електронному мікроскопі ПЕМ-125К.

Результати й обговорення. У першій групі пацієнтів у результаті гістологічного дослідження ділянки шкіри після повної епітелізації опікової 
Огляди літератури, оригінальні дослідження, погляд на проблему, випадок з практики, короткі повідомлення рани ми встановили, що епідерміс представлений шаром епітеліальних клітин, у якому чітко визначаються базальні, остисті, зернисті епідермоцити та шар рогових лусочок. Дерма шкіри в такій ділянці представлена щільною неоформленою сполучною тканиною, сосочковий шар відсутній. Наявні численні фібробласти, тонкі пучки колагенових волокон та багато гемокапілярів (рис. 1).

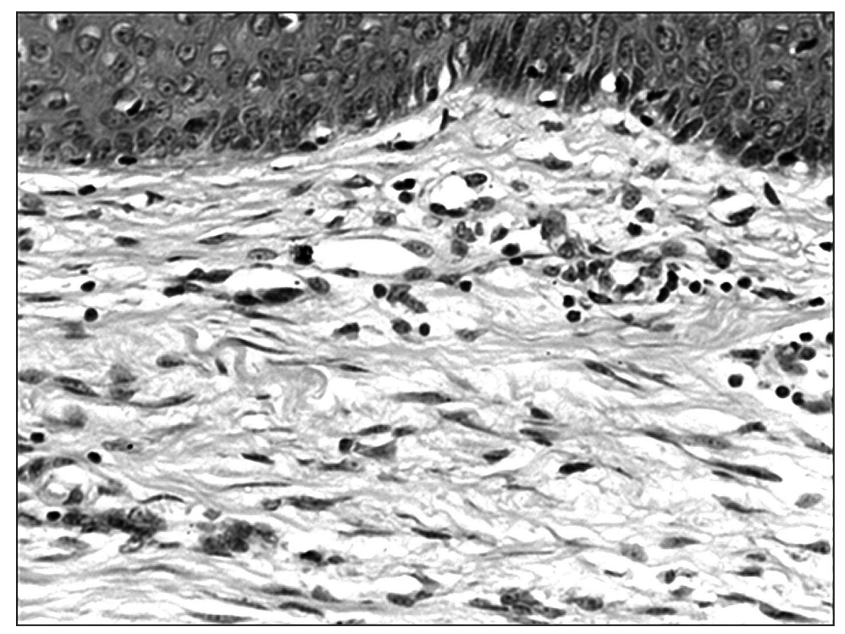

Рис. 1. Початок утворення рубцевої тканини через 5 днів після повної епітелізації опікової рани.
Проведено клінічне обстеження 19 хворих другої групи за допомогою універсальної шкали. Проводилось фотографування рубців (рис. 2). Через 2 і 4 місяці після початку використання силіконових пластин проводили повторне клінічне дослідження рубцевих тканин.

Отримані результати представлені в таблиці 3.

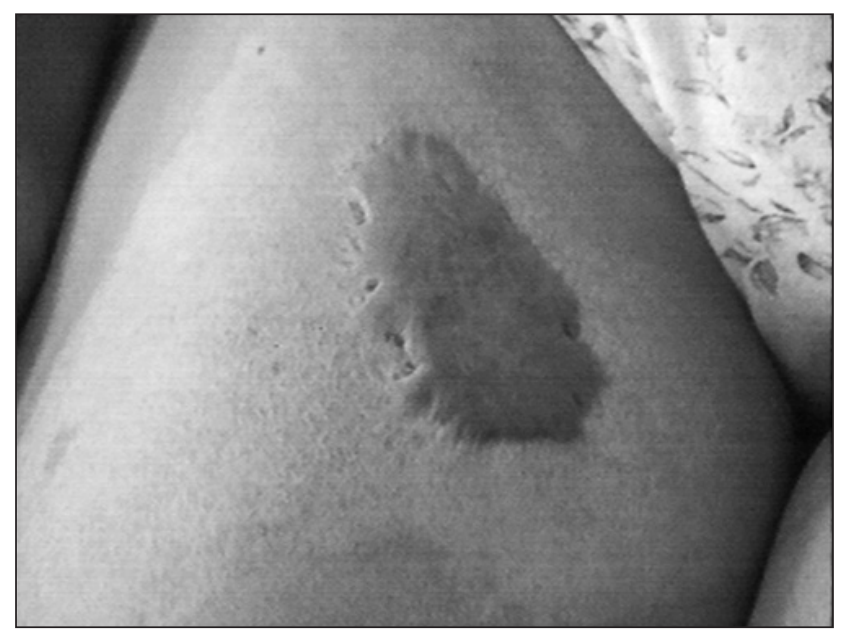

Рис. 2. Зовнішній вигляд келоїдного рубця. Жінка через 1 місяць після епітелізації опікової рани.

Таблиця 3. Розподіл ознак рубців у процесі лікування

\begin{tabular}{|c|c|c|c|}
\hline \multirow{2}{*}{ Ознаки рубця (n=19) } & \multicolumn{3}{|c|}{ Бали $(\mathrm{M} \pm \mathrm{m}, \%)$} \\
\hline & до лікування & через 2 місяці & через 4 місяці \\
\hline Товщина & $2,44 \pm 0,18$ & $2,11 \pm 0,24$ & $1,33 \pm 0,23$ \\
\hline Рівномірність товщини & $1,39 \pm 0,30$ & $1,39 \pm 0,30$ & $0,67 \pm 0,18$ \\
\hline Васкуляризація & $2,00 \pm 0,18$ & $1,78 \pm 0,17$ & $0,83 \pm 0,19$ \\
\hline Пігментація & $0,67 \pm 0,27$ & $0,67 \pm 0,27$ & $0,67 \pm 0,27$ \\
\hline Консистенція & $1,17 \pm 0,26$ & $1,06 \pm 0,22$ & $0,61 \pm 0,18$ \\
\hline Виразкування & $0,22 \pm 0,10$ & 0 & 0 \\
\hline Температура & $1,44 \pm 0,27$ & $0,83 \pm 0,19$ & $0,11 \pm 0,11$ \\
\hline Свербіж, парестезії & $2,00 \pm 0,18$ & $1,39 \pm 0,18$ & $0,61 \pm 0,14$ \\
\hline Прогресування & $1,67 \pm 0,16$ & $0,89 \pm 0,14$ & $0,28 \pm 0,11$ \\
\hline Чутливість & $0,83 \pm 0,17$ & $0,83 \pm 0,17$ & $0,28 \pm 0,16$ \\
\hline
\end{tabular}

Сума балів до початку лікування в середньому складала 13,83, через 2 місяці - 10,9, через 4 місяці використання силіконових пластин - 5,39 балів. Як видно з таблиці, в процесі лікування відбувалося помітне зменшення балів, які характеризували клінічні ознаки рубця, що свідчить про ефективність вказаного методу лікування.

Ефект від застосування силіконових пластин проявлявся розм'якшенням, сплощенням і зменшенням об'єму рубцевої тканини, наближенням кольору шкіри до природного, збільшенням рівня еластичності рубцевої тканини, зниженням висоти рубця відносно рівня здорової шкіри (рис. 3).
Порівняльна оцінка мікроскопічнихі електронномікроскопічних змін рубцевої тканини реконвалесцентів у двох групах хворих при лікуванні опікової хвороби звичайним методом та із застосуванням силікону показала, що при використанні даного методу лікування структурні зміни були менш виражені. Дослідження рубців після застосування силіконових пластин показало, що в сполучній тканині помітно знижувався вміст фібробластів, спроможних до інтенсивного колагеноутворення (рис. 4, 5).

Таким чином, застосування силіконових пластин під час загоєння тяжких опікових ран 
Огляди літератури, оригінальні дослідження, погляд на проблему, випадок з практики, короткі повідомлення

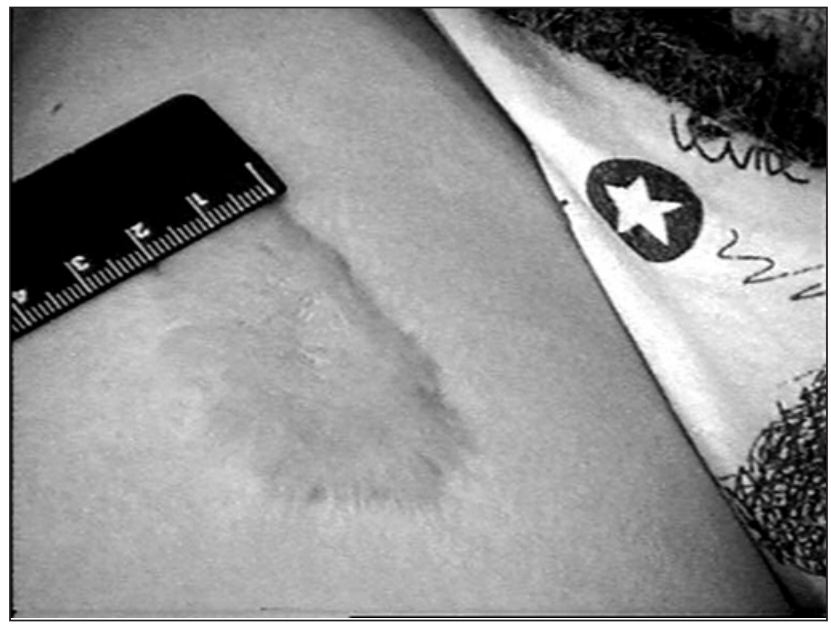

Рис. 3. Зовнішній вигляд келоїдного рубця. Жінка через 4 місяці після використання силіконової пластини.

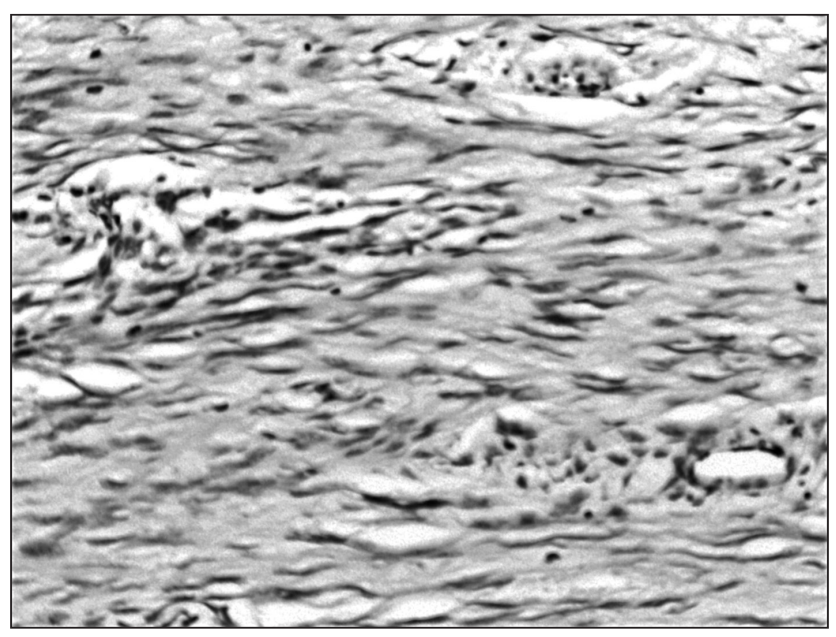

Рис. 5. Гістологічний стан ділянки дерми шкіри при лікуванні з використанням силіконових пластин. Хворий через 4 місяці після початку лікування.

приводило до покращення епітелізації. Спостерігали зникнення запального процесу, значно зменшувалася кількість дерматогенних ускладнень.

Обстежено 16 пацієнтів третьої групи із застарілими (1-3 роки після опіків) гіпертрофічними та келоїдними рубцями, яким була проведена кріодеструкція рубцевих тканин за допомогою рідкого азоту, а рановий дефект закривали клаптями ксенодермоімплантата з наступними аплікаціями силіконових пластин після повної епітелізації післяопераційних ран.

«Старі» келоїди мали матову поверхню, темніший колір з переважанням коричневого відтінку (рожево-коричневого, синювато-коричневого); менш пружну та менш щільну консистенцію, іноді в'ялий поверхневий шар; епідерміс над рубцем можна було зібрати в складку (тобто рубці мали

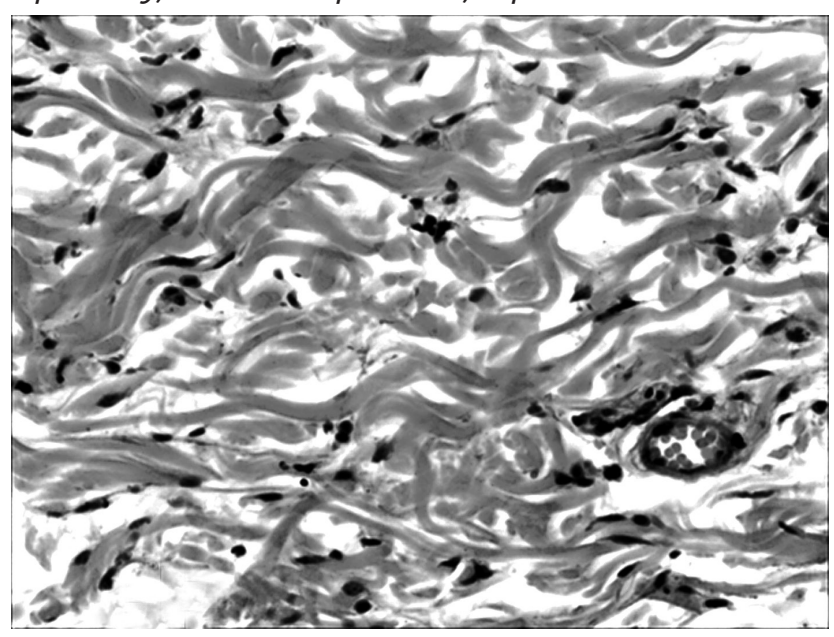

Рис. 4. Гістологічний стан ділянки дерми при лікуванні з використанням силіконових пластин. Хворий через 2 місяці після початку лікування

нерівну, злегка зморшкувату поверхню); зменшувалися або зовсім зникали клінічні прояви.

Клінічний випадок № 1. Хлопчик К., 9 років, перебував на стаціонарному лікуванні з приводу післяопікового келоїдного рубця правої половини обличчя. Останній підвищувався на 1-1,5 см над рівнем неуражених тканин обличчя, відрізнявся білувато-рожевим кольором, щільною консистенцією (рис. 6).

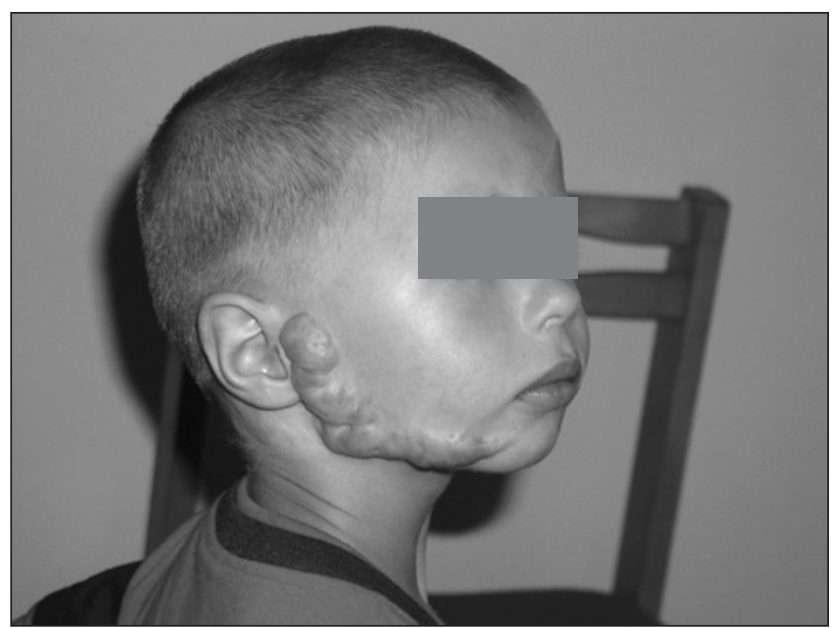

Рис. 6. Клінічний вигляд застарілого келоїдного рубця. Хворий через 1 рік після отриманого опіку.

Наповненим рідким азотом резервуаром проводили кріообробку рубцевої тканини шляхом переміщень по поверхні рубця робочої площини резервуара впродовж 2 хв під загальним знеболюванням (рис. 7). На другу добу видалено міхурі з серозною рідиною в ділянці кріообробки, а на новоутворену рану накладено клапті ксенодермоімплантата (рис. 8). Через 16 діб рани під ксенодермоімплантатами повністю загоїлися шляхом 
Огляди літератури, оригінальні дослідження, погляд на проблему, випадок з практики, короткі повідомлення епітелізації (рис. 9). На місці рубця больових відчуттів, свербежу, парестезій або печії не відмічалося. Пацієнта виписано у задовільному стані під

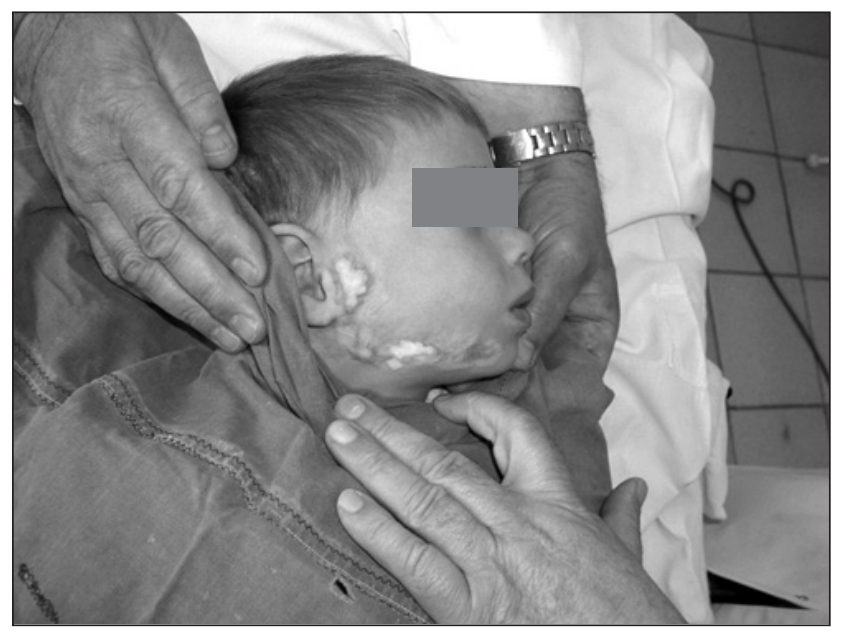

Рис. 7. Вигляд рубцевої тканини одразу після кріодеструкції.

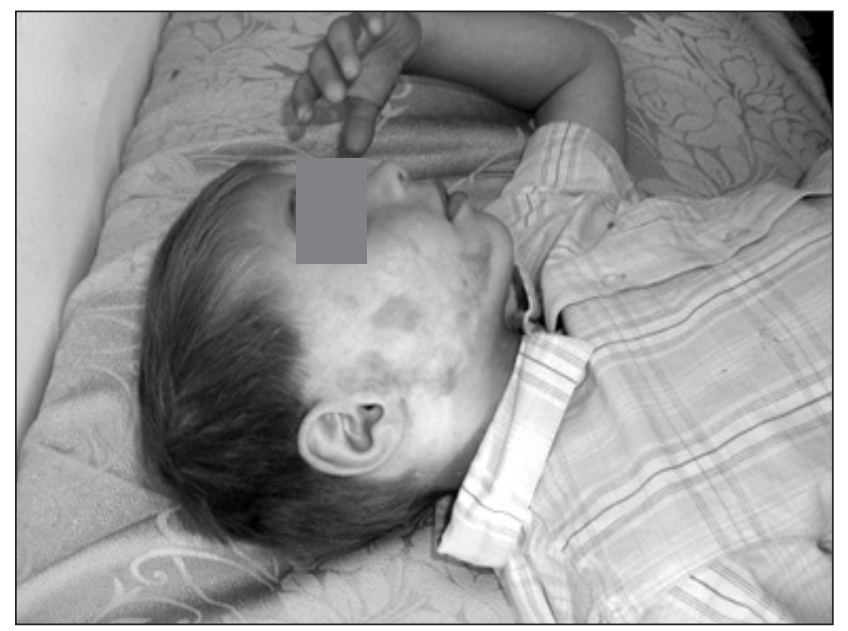

Рис. 9. Вигляд шкірних покривів після повної епітелізації. Хлопчик через 16 діб після проведення кріодеструкції, ксеноімплантації.

Контрольні огляди вказаного хворого проводили кожного місяця протягом 6 місяців використання силіконової пластини (рис. 11).

3 використанням запропонованої методики проведено лікування 16 хворих з келоїдними та гіпертрофічними рубцями. В усіх випадках застосування ксенодермоімплантатів для пластики ранового дефекту після кріодеструкції рубців та використання аплікацій силіконових пластин супроводжувалося позитивними результатами лікування без будь-яких ускладнень в ранньому післяопераційному та віддалених періодах.

Висновки. 1. Патологічні післяопікові рубці за клінічними та морфологічними ознаками поді- амбулаторний нагляд з рекомендаціями використовувати силіконову пластину для профілактики рубцеутворення (рис. 10).

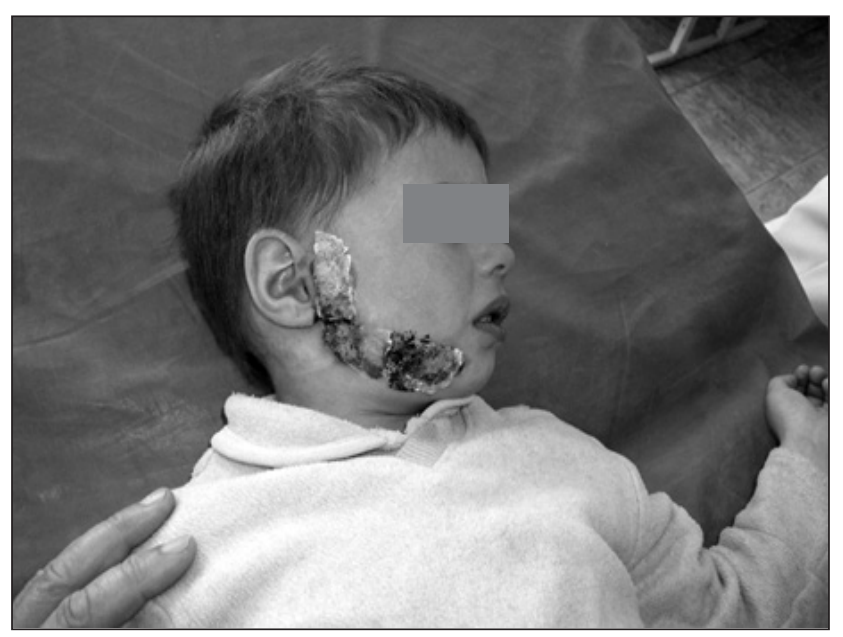

Рис. 8. Вигляд ранової поверхні під ксенодермоімплантатами. Хворий через 5 діб після проведення кріодеструкції рубця.

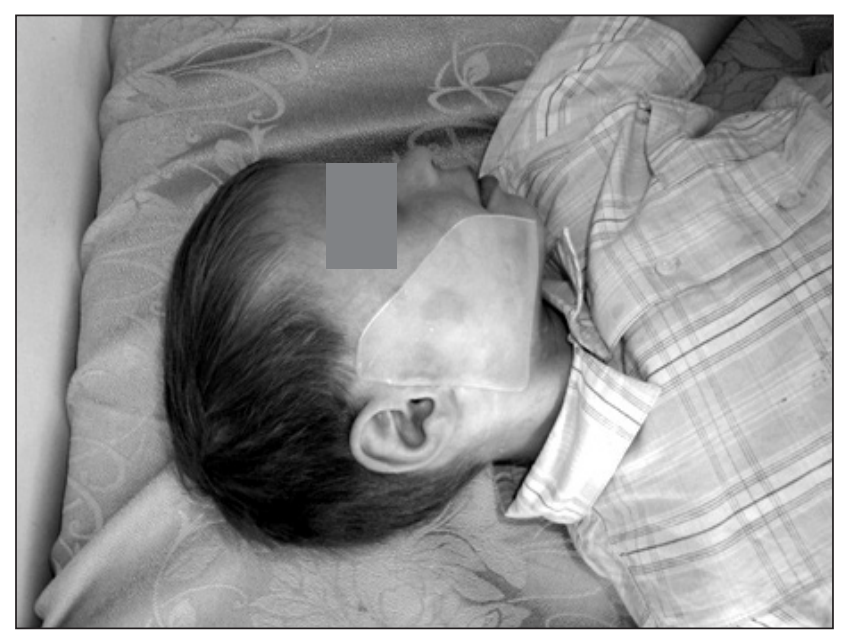

Рис. 10. Використання силіконової пластини. Хлопчик через 5 діб після повної епітелізації рани.

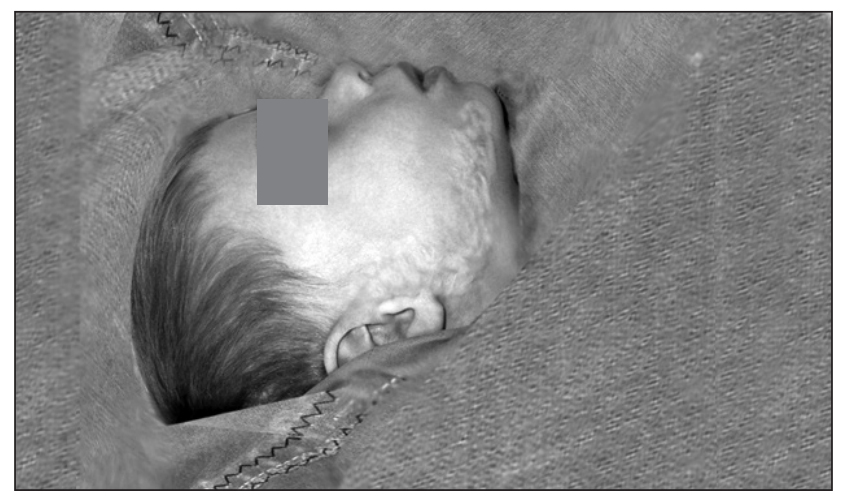

Рис. 11. Вигляд шкірних покривів після 3-місячного використання силіконової пластини. 
Огляди літератури, оригінальні дослідження, поглядн на ляють на гіпертрофічні та келоїдні, в різні терміни після ураження їх будова та біосинтетичні можливості різні. Знання стадій формування рубцевої тканини має велике значення для вибору того чи іншого методу лікування.

3. Клінічно та морфологічно встановлено високу ефективність застосування силіконових пластин та компресійного одягу для профілактики утворення та лікування свіжих гіпертрофічних і келоїдних рубців.

4. Використання кріодеструкції рубцевих тканин з наступною ксеноімплантацією та аплікаціясиліконових пластин забезпечує позитивні результати лікування післяопікових келоїдних та гіпертрофічних рубців і рекомендується для застосування в лікувальній практиці.

Перспективи подальших досліджень. Незважаючи на те, що існує багато методів профілактики утворення рубців, їх результативність не завжди є задовільною. Лікування рубців - це досить довгий та складно прогнозований щодо кінцевого результату процес, який є актуальною клінічною проблемою і потребує негайного вирішення.

\section{ЛІТЕРАТУРА}

1. Бігуняк В. В. Можливості використання субстрату консервованої ксеногенної шкіри: проблеми і перспективи / В.В.Бігуняк, В.В.Дем'яненко, Н.В.Гуда // «Науково-технічний прогрес і оптимізація технологічних процесів створення лікарських препаратів» : матеріали II Міжнародної науково-практичної конференції. - Тернопіль : Укрмедкнига, 2007. - С. 34-36.

2. Использование лиофилизированных ксенодермотрансплантатов в ожоговых отделениях Украины / Т. В. Бігуняк, В. И. Нагайчук, В.В.Дем'яненко, Н.В.Гуда // Актуальные проблемы лечения термических поражений и их последствий : материалы респ. науч.-практ. конф. (г. Минск, 3 октября 2008 года). - Минск : ДокторДизайн, 2008. - С. 87-89.

3. Подрібнений субстрат кріоконсервованої ксеношкіри: новий технологічний етап системної тканинної терапії / В. В. Бігуняк, В. В. Дем'яненко, І. М. Кліщ, Ю. С. П'ятницький // Здобутки клінічної та експериментальної медицини : збірник матеріалів конф., 4 червня 2009 року. - Тернопіль : Укрмедкнига, 2009. - С. 52-53.

4. Дем'яненко В. В. До реалізації фотоннокристалічних процесів у біомедичних технологіях /В.В.Дем'яненко, І. М. Кліщ, А. В. Бігуняк // Науково-технічний прогрес і оптимізація технологічних процесів створення лікарських препаратів : матеріали III Науково-практичної конференції 1-2 жовтня 2009 року. - Тернопіль : Укрмедкнига, 2009. - С.113-114.

5. Патент 46265 U. Спосіб моделювання явища міграції енергії фотона / Дем'яненко В. В., Бігуняк В. В., Кліщ І. М. № 200907394; заявл. 14.07.2009; опубл. 10.12.2009; Бюл. № 23.

6. Позитивне рішення по заявці №u201004841 від 22.04.2010: Спосіб моделювання гідрофобного генератора автоколивань макромолекул живої системи / Дем'яненко В. В., Покришко О. В., Савчишин В. В., Білоус А. П., Богун М. І. Заявник - ТДМУ.

7. Погляд на імпульс як збурювач функції біосистеми / В. В. Бігуняк, В. В. Дем'яненко, К. С. Волков, Ю. П. Щирба // Здобутки клінічної та експериментальної медицини. - 2009. - № 1.

8. Дем'яненко В. В. Компресійна терапія крізь призму рідкого кристалу / В. В. Дем'яненко, В. В. Бігуняк // Здобутки клінічної та експериментальної медицини. - 2006. - № 1. - С. 34-37.
9. Козинець Г. П. Опікова хвороба / Г. П. Козинець, О. Н. Коваленко, С. В. Слєсаренко // Мистецтво лікування. - 2006. - С. 9-15.

10. Дитяча комбустіологія / Е. Я. Фісталь, Г. П. Козинець, Г. Е. Самойленко, В. М. Носенко. - Донецьк, 2006. 233 c.

11. Дем'яненко В. В. Ідентифікація електретних властивостей полімерних матеріалів біомедичного призначення / В.В.Дем'яненко, Ю. С. П'ятницький, Р. К. Волков // Шпитальна хірургія. - 2007. - № 2. C. 67-61.

12. Дем'яненко В. В. Методологічні і методичні підходи до розвитку "силіконових" технологій в медицині / В. В. Дем'яненко, О. В. Покришко, Т. В. Бігуняк // Відновлювальні та профілактичні технології в клінічній медицині : тези доповідей симпозіуму. - Полтава, 2009. - С. 24.

13. Патент на корисну модель № 39667. Спосіб лікування при келоїдних та гіпертрофічних рубцях / Бігуняк В. В., Волков Р. К., 2009.

14. Патент на корисну модель № 44371. Спосіб хірургічного лікування хворих з рубцевою деформацією шкіри / Масляк Р. М., Савчин В. С., 2009 р.

15. Гуда Н. В. Використання силіконових пластин для профілактики рубцеутворення / Н. В. Гуда, А. В. Бігуняк, Р. К. Волков // Відновлювальні та профілактичні технології в клінічній медицині: тези доповідей симпозіуму. - Полтава, 2009. - С. 22-23.

16. Дем'яненко В. В. Силіконова пластинка як фотоннокристалічний індуктор корекції рубцеутворення / В. В. Дем'яненко, А. В. Бігуняк // Морфологічні основи компенсаторно-пристосувальних процесів і їх структурне забезпечення : збірник матеріалів науково-практичної конференції. - Тернопіль, 2008. - С. 27-29.

17. Бигуняк В. В. Применение силиконовых пластин для профилактики и лечения рубцов у ожоговых реконвалесценток / В. В. Бигуняк, Н. В. Гуда, А. В. Цимбалюк : II съезд ассоциации врачей экстренной медицинской помощи, посвященный десятилетию службы экстренной медицинской помощи республики Узбекистан, 21-22 октября 2011 г. - Ташкент, 2011. - С. 56-57.

18. Ожоги : руководство для врачей / под ред. Б. А. Парамонова, Я. О. Порембского, В. Г. Яблонского. Спб. : Спецлит, 2000. - 488 с., ил. 
Огляди літератури, оригінальні дослідження, погляд на проблему, випадок з практики, короткі повідомлення

19. Белоцкий С. Раны и повязки. Современные концепции и практика / С. Белоцкий, Р. Брейтман. - Израиль, 2000. -280 с.

20. Ожоговая травма : рекомендации для практических врачей / [С. В. Слесаренко, Г. П. Козинец, Е. Н. Клигуненко и др.]. - Днепропетровск, 2002. - 60 с.

21. Фисталь Э. Я. Современные принципы лечения больных с глубокими ожогами / Э. Я. Фисталь // Актуальне вопросы диагностики и лечения ожоговой травмы : тезисы докладов и лекций. - Одесса, 2004. - С. 43-47.

22. Слєсаренко С. В. Оцінка ефективності компресійної терапії у пацієнтів з посляопіковими рубцями / С. В. Слєсаренко, П. О. Бадюл // Хірургія України. 2006. - № 2 (18). - C. 47-53.

23. Objective assessment of burn scar vascularity, erythema, pliability, thickness, and planimetry G. V. Oliveira [et al.] // Dermatol. Surg. - 2005. - Vol. 31. - P. 48-58.

24. What is the prevalence of hypertrophic scarring following burns? / K. M. Bombaro [et al.] // Burns. - 2003. Vol. 29. - P. 299-302.

\section{REFERENCES}

1. Bihuniak, V.V., Demianenko, V.V., \& Huda, N.V. (2007) Mozhlyvosti vykorystannia substratu konservovanoi ksenohennoi shkiry: problemy i perspektyvy [Possibilities of using canned xenogenic skin substrate: problems and prospects]. Naukovo-tekhnichnyi prohres $i$ optymizatsiia tekhnolohichnykh protsesiv stvorennia likarskykh preparativ. Materialy II-i mizhnarodnoi naukovo-praktychnoi konferentsii - Scientific and Technological Progress and Optimization of Technological Processes of Drug Preparation. Proceedings of the II International Scientific-practical Conference. Ternopil: Ukrmedknyha [in Ukrainian].

2. Bigunyak, T.V., Nagaychuk, V.I., Demyanenko, V.V., \& Guda, N.V. (2008). Ispolzovanye lyofylyzyrovannykh ksenodermotransplantatov $v$ ozhohovykh otdelenyyakh Ukrainy [Use of lyophilized xenodermotransplants in burn departments of Ukraine]. Aktualnye problemy lecheniya termicheskykh porazheniy i ikh posledstviy. Materialy resp. nauch.-prakt. konf. - Actual problems of treatment of thermal lesions and their consequences. Scientific-practical Conf. Minsk: "Doktor-Dizayn" [in Russian].

3. Bihuniak, V.V., Demianenko, V.V., Klishch, I.M., \& Piatnytskyi, Yu.S. (2009). Podribnenyi substrat kriokonservovanoi ksenoshkiry: novyi tekhnolohichnyi etap systemnoi tkanynnoi terapii [Crushed substrate of cryopreserved xenoscope: a new technological stage of systemic tissue therapy]. Zdobutky klinichnoi ta eksperymentalnoi medytsyny. Zbirnyk materialiv konf. - Clinical and Experimental Medicine. Collection of Conf. Materials Ternopil: TDMU, Ukrmedknyha [in Ukrainian].

4. Demianenko, V.V., Klishch, I.M., \& Bihuniak, A.V. (2009). Do realizatsii fotonnokrystalichnykh protsesiv u biomedychnykh tekhnolohiiakh [Towards the realization of photocrystalline processes in biomedical technologies]. Naukovo-tekhnichnyi prohres i optymizatsiia tekhnolohichnykh protsesiv stvorennia likarskykh preparativ. Materialy III naukovo-praktychnoi konferentsii - Scientific and Technological Progress and Optimization of Technological Processes
25. Hamanova $\mathrm{H}$. Influence of inadequate prehospital and primary hospital treatment on the maturation of scars after thermal injuries / H. Hamanova, L. Broz // Acta Chir Plast. - 2003. - Vol. 45. - P. 18-21.

26. Alster T. S. Hypertrophic scars and keloids: etiology and management / T. S. Alster, E. L. Tanzi // Am. J. Clin. Dermatol. - 2003. - Vol. 4. - P. 235-243.

27. Sund B. New developments in wound care / B. London: PJB Publications. - 2000. - P. 1-255. (Clinica Report CBS 836.)

28. Bayat A. Skin scarring. Clinical review / A. Bayat, D. A. McGrouther, M. W. J. Ferguson // BMJ. - 2003. Vol. 326, No. 11. - P. 88-92.

29. New directions in tissue repair and regeneration. Phil. Trans. R. 2004, The Royal Society DOI Soc. Lond. B (2004) 359, 839-850.- 10.1098/rstb.2004.1475 840

30. International advisory panel on scar management. International clinical recommendations on scar management / T. A. Mustoe, R. D. Cooter, M. H. Gold, [et al.] // Plast Reconstr Surg. - 2002. - Vol. 110. - P. 560-571.

for the Creation of Medicinal Products. Proceedings of the 3rd Scientific and Practical Conference. Ternopil: "Ukrmedknyha" [in Ukrainian].

5. Demianenko, V.V., Bihuniak, V.V., \& Klishch, I.M. (2009). UA Patent 46265. Kyiv: State Patent Office of Ukraine [in Ukrainian].

6. Demianenko, V.V., Pokryshko, O.V., Savchyshyn, V.V., Bilous, A.P., \& Bohun, M.I. (2010). UA Patent №u201004841. Kyiv: State Patent Office of Ukraine [in Ukrainian].

7. Bihuniak, V.V., Demianenko, V.V., Volkov, K.S., \& Shchyrba, Yu.P. (2009). Pohliad na impuls yak zburiuvach funktsiii biosystemy [A looking at the impulse as a biosystems disruptor]. Zdobutky klinichnoi ta eksperymentalnoi medytsyny - Achievements in Clinical and Experimental Medicine, 1 [in Ukrainian].

8. Demianenko, V.V., \& Bihuniak, V.V. (2006). Kompresiina terapiia kriz pryzmu ridkoho krystalu [Compression therapy through the prism of liquid crystal]. Zdobutky klinichnoi ta eksperymentalnoi medytsyny Achievements of Clinical and Experimental Medicine, 1, 3437 [in Ukrainian].

9. Kozinets, H.P., Kovalenko, O.N., \& Slesarenko, S.V. (2006). Opikova khvoroba [Burning disease]. Mystetstvo likuvannia - The Art of Healing, 9-15 [in Ukrainian].

10. Fistal, E.Ya., Kozynets, H.P., Samoilenko, H.E., \& Nosenko, V.M. (2006). Dytiacha kombustiolohiia [Pediatric combustiology]. Donetsk [in Ukrainian].

11. Demianenko, V.V., Piatnytskyi, Yu.S., \& Volkov R.K. (2007). Identyfikatsiia elektretnykh vlastyvostei polimernykh materialiv biomedychnoho pryznachennia [Identification of electret properties of polymeric materials of biomedical purpose]. Shpytalna khirurhiia - Hospital Surgery, 2, 67-61 [in Ukrainian].

12. Demianenko, V.V., Pokryshko, O.V., \& Bihuniak, T.V. (2009). Metodolohichni i metodychni pidkhody do rozvytku "sylikonovykh" tekhnolohii v medytsyni [Methodological and methodological approaches to the development of 
Огляди літератури, оригінальні дослідження, погляд на проблему, випадок з практики, короткі повідомлення "silicone" technologies in medicine]. "Vidnovliuvalni ta profilaktychni tekhnolohii v klinichnii medytsyni": tezy dopovidei sympoziumu - "Restorative and Preventive Technologies in Clinical Medicine ": Abstracts of the Symposium. Poltava [in Ukrainian].

13. Bighuniak, V.V., \& Volkov, R.K. (2009). UA Patent 39667. Kyiv: State Patent Office of Ukraine [in Ukrainian].

14. Masliak, R.M., \& Savchyn, V.S. (2009). UA Patent 44371. Kyiv: State Patent Office of Ukraine [in Ukrainian].

15. Huda, N.V., Bihuniak, A.V., \& Volkov, R.K. (2009). Vykorystannia sylikonovykh plastyn dlia profilaktyky rubtseutvorennia [The use of silicone plates for the prevention of scar formation]. Vidnovliuvalni ta profilaktychni tekhnolohii v klinichnii medytsyni": tezy dopovidei sympoziumu - "Restorative and preventive technologies in clinical medicine": Abstracts of the Symposium. Poltava [in Ukrainian].

16. Demianenko, V.V., \& Bihuniak, A.V. (2008). Sylikonova plastynka yak fotonnokrystalichnyi induktor korektsii rubtseutvorennia [Silicone plate as photonic crystal inducer of correction of scar formation]. Morfolohichni osnovy kompensatorno-prystosuvalnykh protsesiv i yikh strukturne zabezpechennia: zbirnyk materialiv naukovo-praktychnoi konferentsii - Morphological Bases of Compensatory-Adaptive Processes and their Structural Support: A Collection of Scientific and Practical Materials Conferences. Ternopil [in Ukrainian].

17. Bigunyak, V.V., Guda, N.V., \& Tsimbalyuk, A.V. (2011). Primenenye sylykonovykh plastin dlya profilaktiky i lecheniya rubtsov u ozhogovykh rekonvalestsentok [Application of silicone plates for the prevention and treatment of scars in burn convalescents]. 2 syezd assotsyatsiy vrachey ekstrennoy medytsynskoy pomoshchi, posvyashchennyy desyatiletiyu sluzhby ekstrennoy medytsynskoy pomoshchi respubliky - the 2nd Congress of the Emergency Medical Aid Association, dedicated to the decade of emergency medical service assistance of the Republic of Uzbekistan, 56-57 [in Russian].

18. Paramonov, B.A., Porembsky, Ya.O., \& Yablonskyy, V.G. (Eds.). (2000). Ozhogy: Rukovodstvo dlya vrachey [Burns: A guide for doctors]. Saint-Petersburg: Spetslit [in Russian].

19. Belotskiy, S., \& Breitman, R. (2000). Rany $i$ povyazki. Sovremennyye kontseptsii i praktika [Wounds and dressings. Modern Concepts and Practice]. Ramat Gan: V DDB [in Russian].

20. Slesarenko, S.V., Kozinets, G.P., \& Kligunenko, Ye.N. (2002). Ozhogovaya travma: rekomendatsii dlya prakticheskikh vrachey [Burn injury: recommendations for practitioners]. Dnipropetrovsk [in Russian].

21. Fistal, E.Y. (2004). Sovremennyye printsipy lecheniya bolnykh s glubokimi ozhogami [Modern principles of treatment of patients with deep burns]. Aktualnye voprosy diagnostiki i lecheniya ozhogovoy travmy. Tezisy dokladov $i$ lektsiy - Topical issues of diagnosis and treatment of burn injury. Abstracts and lectures. Odesa [in Russian].

22. Slesarenko, S.V., \& Badul, P.O. (2006). Otsinka efektyvnosti kompresiinoi terapii u patsiientiv z pisliaopikovymy rubtsiamy [Evaluation of the effectiveness of compression therapy in patients with post-burn scars]. Khirurhiia Ukrainy - Surgery of Ukraine, 2 (18), 47-53 [in Ukrainian].

23. Oliveira, G.V. (2005). Objective assessment of burn scar vascularity, erythema, pliability, thickness, and planimetry. Dermatol. Surg, 31, 48-58.

24. Bombaro, K.M. (2003). What is the prevalence of hypertrophic scarring following burns? Burns, 29, 299-302.

25. Hamanova, H., \& Broz, L. (2003). Influence of inadequate prehospital and primary hospital treatment on the maturation of scars after thermal injuries. Acta Chir. Plast, 45, 18-21.

26. Alster, T.S., Tanzi, E.L. (2003). Hypertrophic scars and keloids: etiology and management. Am. J. Clin. Dermatol., 4, 235-243.

27. Sund, B. (2000). New developments in wound care. London: PJB Publications, 1-255 (Clinica Report CBS 836.)

28. Bayat, A., Mc Grouther, D.A., \& Ferguson, M.W.J. (2003). Skin scarring. Clinical review BMJ, 326 (11), 88-92.

29. (2004). New directions in tissue repair and regeneration. The Royal Society, 359, 839-850. 10.1098/ rstb.2004.1475 840

30. Mustoe, T.A., Cooter, R.D., Gold, M.H., Hobbs, F.D., Ramelet, A.A., Shakespeare, P.G. et al (2002). International advisory panel on scar management. International clinical recommendations on scar management. Plast. Reconstr. Surg., 110, 560-571.

\section{ЭФФЕКТИВНОСТЬ ИСПОЛЬЗОВАНИЯ КОМПРЕССИОННОЙ ОДЕЖДЫ И СИЛИКОНОВИХ ПЛАСТИН ДЛЯ ПРОФИЛАКТИКИ И ЛЕЧЕНИЯ ПАТОЛОГИЧЕСКИХ РУБЦОВ КОЖИ У ПАЦИЕНТОВ ПОСЛЕ ТРАВМ И ОПЕРАЦИЙ}

ФР. К. Волков

Тернопольский национальный медицинский университет имени И. Я. Горбачевского МОЗ Украины

РЕЗЮМЕ. Реабилитация пострадавших с ожогами, травмами и после операций всегда была и остается актуальной в связи с тем, что даже ограниченные поражения кожи, которые не представляют проблемы для хирурга в плане их заживления или оперативного лечения, могут вызвать развитие рубцовых массивов с деформациями, контрактурами, алопециями и трофическими язвами. Несмотря на то, что существует много методов профилактики и лечения рубцов, их результативность не всегда остается удовлетворительной.

Цель - изучить эффективность профилактики и лечения послеожоговых гипертрофических и келоидных рубцов на основе изучения клинико-морфологических особенностей их формирования при использовании аппликаций силиконовых пластин и компрессионной одежды.

Материал и методы. Проведено сравнение эффективности профилактических и лечебных мероприятий у 65 больных с послеожоговыми рубцами, которые возникли после поверхностных и глубоких ожогов площадью 
Огляди літератури, оригінальні дослідження, погляд на проблему, випадок з практики, короткі повідомлення от 5 до 20 \% поверхности тела. Среди обследованных больных с ожогами было 30 человек (46,2 \%) мужского и 35 (53,8 \%) женского пола в возрасте от 9 до 64 лет. Пациенты были поделены на 3 группы. В первую группу вошли 30 больных, у которых через 3-5 дней после полной эпителизации ожоговых ран использовали силиконовые пластины и компрессионную одежду на участки, в которых началось образование рубцов. Во вторую - 19 больных, которым силиконовые пластины и компрессионную одежду использовали через 20-30 дней после полной эпителизации ожоговых ран. Третью группу составили 16 пациентов со старыми (1-3 года после ожогов) рубцами которым была проведена криодеструкция, ксенопластика с аппликациями силиконовых пластин после полной эпителизации послеоперационных ран.

Результаты. В результате клинического обследования пациентов первой группы, которые в течение 4 месяцев использовали аппликации силиконовых пластин и компрессионную одежду, только у двоих пациентов (6,7 \%) выявлены гипертрофические рубцы, которые привели к незначительным косметическим дефектам кожных покровов, у 9 (30 \%) пациентов отмечался ярко-розовый цвет кожных покровов в течение первых двух месяцев, у всех остальных 19 (63,3 \%) пациентов образования патологических рубцов не обнаружено.

Анализ результатов лечения второй группы (19 пациентов), которым силиконовые пластины накладывали на гипертрофические и келоидные рубцы через 20-30 дней после эпителизации ожоговых ран в течение 4 месяцев, проводился с использованием универсальной шкалы. Общая сумма баллов после проведенного лечения уменьшилась в 2,6 раза, что свидетельствует о значительной эффективности данного метода лечения. Электронно-микроскопические исследования рубцов после применения силиконовых пластин показало, что в соединительной ткани заметно снижалось содержание фибробластов, способных к интенсивному образованию коллагена. Применение силиконовых пластин во время заживления тяжелых ожоговых ран приводило к улучшению эпителизации, исчезновению воспалительного процесса, значительному уменьшению количества дерматогенных осложнений.

Выводы. Клинически и морфологически установлена высокая эффективность применения силиконовых пластин и компрессионной терапии, а также криодеструкции с ксенопластикой, для профилактики образования и лечения патологических рубцов. рубец.

КЛЮчЕВЫЕ СЛОВА: силиконовые пластины; компрессионная одежда; келоидный рубец; гипертрофический

\section{THE EFFECTIVENESS OF THE USAGE OF COMPRESSION CLOTHING AND SILICONE PLATES FOR PREVENTION AND TREATMENT OF PATHOLOGICAL SCARS OF PATIENTS AFTER INJURIES AND OPERATIONS}

\section{Horbachevsky Ternopil National Medical University}

@R. K. Volkov

SUMMARY. Rehabilitation of burn injury, traumas and after operations has always been on the table and it still is because even restricted damage of skin which doesn't cause any problems for a surgeon concerning its healing or surgical treatment can cause development of scar masses with deformities, contractures, alopecia and trophic ulcers. Despite the fact that there are a lot of methods of prevention and treatment of scars, their results aren't always reassuring.

The aim is to study the effectiveness of prevention and treatment of postburn hypertrophic and keloid scars on the basis of the studying of clinic and morphological peculiarities of their formation by using of silicon plates and compression clothing.

Material and Methods. There have been made a comparison of the effectiveness of prevention and treatment of 65 patients with burn injury which occurred after superficial and deep burns spacing from 5 to $20 \%$ of the body surface. There were 30 (46.2\%) men among those who were examined having scars and 35 (53.8 \%) of them were women at the age of 9-64. Patients were divided into 3 groups. Group 1 included 30 patients in whom 3-5 days after the complete epithelization of burn wounds, silicone plates and compression clothing were used on the sites where scar formation had begun. Group 2 - 19 patients who used silicone plates and compression clothing 20-30 days after the complete epithelization of burn wounds. Group 3 consisted of 16 patients with old (1-3 years after burns) scars who underwent cryodestruction, xenoplasty with applications of silicone plates after complete epithelization of postoperative wounds.

Results. Hypertrophic scars were formed only in two patients (6.7 \%) in group 1 of patients, which led to minor cosmetic defects of the skin, in 9 (30\%) patients color of the scars was bright pink during the first two months, other 19 (63.3\%) patients had no pathological scarring. The total score after treatment decreased by 2.6 times, which indicates the significant effectiveness of this method of treatment in group 2 of 19 patients. Electron microscopy examination of scars showed reducing the number of fibroblasts that could intensively form collagen. During the healing of severe burn wounds epithelialization was faster, the inflammatory process disappeared, and the number of dermatogenic complications decreased significantly.

Conclusions. Clinically and morphologically, the usage of compression clothing and silicone plates, cryodestruction with xenoplasty for prevention and treatment of pathological scars has proven high efficiency

KEY WORDS: silicon plates; compression clothes; keloid scar; hypertrophic scar. 